\section{Comparative study of the clinical and echodopplercardiographic aspects of left ventricular hypertrophy and hypertrophic cardiomyopathy in cats (Felis catus)}

\author{
Estudo comparativo dos aspectos clínicos e \\ ecodopplercardiográficos da hipertrofia ventricular esquerda e \\ da cardiomiopatia hipertrófica em felinos (Felis catus)
}

\author{
Bruno Ricardo Soares Alberigi da Silva* (1), Alexandre José Rodrigues Bendas ${ }^{2}$ (1), Denise do Vale Soares ${ }^{3}$ (D), \\ Renan Salhab Demo ${ }^{4}$ (D), Mateus Fernando Senra de Almeida ${ }^{4}$ (1) \& Jonimar Pereira Paiva ${ }^{5} \dagger$ (D) \\ 'Veterinary, doctorate, MSc. Programa de Pós-graduação em Medicina Veterinária - PPGMV, Universidade Federal Rural do Rio \\ de Janeiro - UFRRJ, Seropédica, RJ, Brasil \\ Veterinary, doctorate, MSc. Programa de Pós-graduação em Medicina Veterinária (Clínica e Reprodução Animal), Universidade \\ Federal Fluminense - UFF, Niterói, RJ, Brasil \\ Veterinary. Instituto de Especialidades em Medicina Veterinária - IEMEV, Rio de Janeiro, RJ, Brasil \\ ${ }^{4}$ Undergraduate students. Universidade Federal Rural do Rio de Janeiro - UFRRJ, Seropédica, RJ, Brasil \\ ${ }^{5}$ Veterinary, Dr. Departamento de Medicina e Cirurgia Veterinária, Universidade Federal Rural do Rio de Janeiro - UFRRJ, \\ Seropédica, RJ, Brasil \\ tDeceased
}

\begin{abstract}
The aim of the present study was to differentiate hypertrophic cardiomyopathy (HCM) from concentric left ventricular hypertrophy (CLVH) and to compare their echodopplercardiography measurements in random bred domestic cats. After owners consent 135 cats of any sex or age with no history of heart disease were randomly submitted to physical examination and echocardiogram. When left ventricular hypertrophy was present on the echocardiogram, cats were further examined by chest X-rays, abdominal ultrasonography and laboratory work. Those presenting cardiac hypertrophy with the diagnosis of any disease that could cause left ventricular hypertrophy were allocated into one group (CLVH) and those presenting hypertrophy without any concomitant detectable disease were allocated to another group (HCM). Cats with ventricular hypertrophy cats were included $(n=10)$, among which five were classified as secondary CLVH, with hyperthyroidism being the main cause and five characterized as HCM. Considering the diagnosis of concentric ventricular hypertrophy, other diseases should be investigated and ruled out, such as hyperthyroidism. It is also necessary to consider and monitor cardiac changes more closely, since their phenotypic manifestation was more severe than those observed in the animals with HCM. However, to determine whether disease progression in these animals is faster severer than in others, further epidemiological studies are necessary.
\end{abstract}

Keywords: feline, echocardiogram, heart disease, hyperthyroidism.

\section{Resumo}

O objetivo do presente estudo foi diferenciar a cardiomiopatia hipertrófica (CMH) da hipertrofia ventricular concêntrica (HVC) e comparar suas medidas ecodopplercardiográficas em gatos domésticos criados aleatoriamente. Após o consentimento dos proprietários, 135 gatos de qualquer sexo ou idade sem história de doença cardíaca foram submetidos aleatoriamente ao exame físico e ao ecocardiograma. Quando a hipertrofia ventricular esquerda estava presente no ecocardiograma, os gatos foram examinados posteriormente por radiografias de tórax, ultrassonografia abdominal e exames laboratoriais. Aqueles que apresentavam hipertrofia cardíaca com o diagnóstico de qualquer doença que pudesse causar hipertrofia ventricular esquerda foram alocados em um grupo (HVC) e aqueles que apresentavam hipertrofia sem qualquer doença detectável concomitante foram alocados em outro grupo (CMH). Gatos com gatos com hipertrofia ventricular foram incluídos $(n=10)$, dos quais cinco foram classificados como HVC secundários, sendo o hipertireoidismo a principal causa e cinco caracterizados como CMH. Considerando o diagnóstico de hipertrofia ventricular concêntrica, outras doenças devem ser investigadas e descartadas, como o hipertireoidismo. Também é necessário considerar e monitorar as alterações cardíacas mais de perto,

\section{BJ $\mathrm{M}$}

Brazilian Journal of Veterinary Medicine

p-ISSN 0100-2430

How to cite: Alberigi, B.R.S., Bendas, A. J. R. Soares, D. V., Demo, R. S., Almeida, M. F. S., \& Paiva, J. P. (2019). Comparative study of the clinical and echodopplercardiographic aspects of left ventricular hypertrophy and hypertrophic cardiomyopathy in cats (Felis catus). Brazilian Journal of Veterinary Medicine, 41, e103419. doi: 10.29374/2527-2179.bjvm103419

Financial support: This study was financed in part by the Coordenação de Aperfeiçoamento de Pessoal de Nível Superior - Brasil (CAPES) Finance Code 001.

Conflict of interests: No conflict of interests declared concerning the publication of this article.

Received: February 16, 2019.

Accepted: May 16, 2019.

Thestudy was carried out at Hospital Veterinário, Universidade Federal Rural do Rio de Janeiro UFRRJ and Instituto de Especialidades em Medicina Veterinária, Rio de Janeiro, RJ, Brasil.

\section{*Correspondence}

Bruno Ricardo Soares Alberigi da Silva Programa de Pós-graduação em Medicina Veterinária - PPGMV, Universidade Federal Rural do Rio de Janeiro - UFRRJ Rodovia BR 465, Km 07, s/n Zona Rural CEP 23890-000 - Seropédica (RJ), Brasil E-mail: bruno.alberigi@gmail.com

Copyright Alberigi et al. This is an Open Access article distributed under the terms of the Creative Commons Attribution Non-Commercial License which permits unrestricted non-commercial use, distribution, and reproduction in any medium provided the original work is properly cited. 
uma vez que sua manifestação fenotípica foi mais severa do que aquelas observadas nos animais com CMH. No entanto, para determinar se a progressão da doença nesses animais é mais rápida do que em outros, mais estudos epidemiológicos são necessários.

Palavras-chave: felino, ecocardiograma, doença cardíaca, hipertireoidismo.

\section{Introduction}

Hypertrophic cardiomyopathy (HCM) is characterized by a concentric hypertrophy of the left ventricle without volume enlargement (Côté et al., 2011b). This hereditary disease of incomplete penetrance has been well described for purebred cats like Maine Coon, Ragdoll, American Short Hair, English Short Hair (Meurs et al., 2005, 2007), Sphynx (Chetboul et al., 2012) and Persian (Trehiou-Sechi et al., 2012). Cardiomyocyte hypertrophy can be present in different cardiopathies, although the myofibrillar disorder is characteristic of HCM (Maron et al., 1982).

Both HCM and concentric left ventricle hypertrophy (CLVH) present similar phenotype although different etiology. HCM is genetically determined and CLVH is secondary to different diseases and conditions such as aortic stenosis, arterial hypertension, chronic kidney disease, hyperthyroidism and hyperaldosteronism (Côté et al., 2011a; Marino et al., 2014). Most of the studies on feline cardiopathies, due to their genetic origin, are concentrated in purebred cats, therefore, the aim of the present study was to differentiate HCM from CLVH and to compare their echodopplercardiography measurements in random bred domestic cats.

\section{Material and methods}

This study was approved by the animal use committee CEUA-FAPUR protocol number 01-05-13.

After owners consent 135 cats of any sex or age presented to UFRRJ or IEMEV with no history of heart disease were randomly submitted to physical examination and echocardiogram. The echocardiographic evaluation was always performed by the same operator, using $\mathrm{m}$-mode, two-dimensional mode and spectral Doppler evaluation to identify those with left ventricular hypertrophy.

All procedures were performed with the cats manually restrained by their owners, under no sedation. All cats presenting left ventricular wall or ventricular septum in diastole over $5 \mathrm{~mm}$ (Ware, 2011; Häggström et al., 2016) were included in the study and further evaluated by Doppler blood pressure measurement, as suggested by Acierno et al. (2018) after acclimatized; physical exam; chest x-rays; abdominal ultrasound and laboratory work. The physical exam was always performed by the same veterinarian, as well as the radiographic and ultrasonographic evaluation.

Urine was collected by cystocentesis for urinalysis and urinary protein/ creatinine ratio determination. Blood samples were collected after 8 hours fasting for blood urea nitrogen (BUN), creatinine, sodium, potassium, ionic calcium, phosphorus and total T4 (radioimmunoassay). Azotemic cats repeated BUN, creatine and blood pressure measurement exams after 7 days to ensure the result (International Renal Interest Society, 2017).

Cats not presenting clinical signs of the disease that could induce CLVH were classified as HCM and cats with those clinical signs, especially considering laboratory work, blood pressure and image results were classified as CLVH. When chronic kidney disease (CKD) was detected, it was only considered as causing ventricular hypertrophy when the cat presented persistent azotemia and blood hypertension associated with ultrasound detected kidney morphology change.

Regarding chronic kidney disease (CKD), only animals with left ventricular hypertrophy were staged according to the International Renal Interest Society (2017).

A descriptive and comparative statistical analysis of the age group was performed using Fisher's exact test. Doppler echocardiographic variables were analyzed by mean and standard deviation and a variation of data using the coefficient of variation. The comparison of Doppler echocardiographic variables between groups (HCM and CLVH) was performed using the Mann Whitney test. The significance level adopted for all samples was $\mathrm{p} \leq 0.05$. BioEstat, version $5.3^{\circledast}$. 


\section{Results}

Ten left ventricular hypertrophy cats were identified and out of those, five were classified as HCM and five as CLVH. Among the CLVH cats, hypertiroidism was the cause for hypertrophy for four cats and for one cat blood hypertension secondary to chronic kidney disease (stage II) was the cause (Table 1).

CLVH cats were older than HCM cats $(\mathrm{U}=2 ; \mathrm{p}=0.0141)$. The mean age for CLVH was $14.8 \pm 4.9$ years and for HCM cats $5.8 \pm 2.8$ years.

Although the majority of the cats with left ventricular hypertrophy were females (4/5 CLVH and $3 / 5$ HCM), there was no statistic difference by sex ( $p=0.3957)$.

Abdominal ultrasound revealed abnormalities in renal morphology of cats of both groups with similar frequency $(\mathrm{p}=0.5000)$ between cats with $\mathrm{CLVH}(\mathrm{n}=4)$ and those with $\operatorname{HCM}(\mathrm{n}=3)$.

Chest $\mathrm{x}$-rays of the HCM cats suggested bilateral enlargement of the heart in 2 animals and right atrium enlargement in 3. In CLVH cats the radiographic exam suggested right atrium enlargement in 3 animals; bilateral enlargement in 1 and another one with no cardiac silhouette change.

Most HCM and CLVH cats echocardiography measurements were similar. Differences were: HCM cats presented lager measurements of Left atrium (LA) $(U=3.5 ; p=0.0301)$, left ventricle in diastole (LVd) $(\mathrm{U}=1.5 ; \mathrm{p}=0.0108)$ and left ventricle in systole $(\mathrm{LVs})(\mathrm{U}=4.5 ; \mathrm{p}=0.0473)$ while: left ventricular wall in diastole (LVWd) measurement was largest for CLVH cats (Table 2).

Besides those variations, one HCM cat presented systolic anterior movement of the mitral valve (SAM) and another cat presented dynamic obstruction of the left ventricular outflow tract (LVOT). Two of the CLVH cats presented both SAM and LVOT and in one of them mitral valve insufficiency was also observed.

\section{Discussion}

The percentage of HCM cats among the left ventricle concentric hypertrophic cats (3.7\%) was lower than the expected 10 - 15\% (Côté et al., 2011b; Fox, 1999; Paige et al., 2009; Abbott, 2010; Branquinho et al., 2010) what might have been influenced by the number of females included, once males are known to be more predisposed to HCM than females (Fox, 1999; Rush et al., 2002).

Table 1. Laboratory tests results, measurement of systolic blood pressure and ultrasonography exam of random bred cats with hypertrophic cardiomyopathy and secondary concentric ventricular hypertrophy.

\begin{tabular}{|c|c|c|c|c|c|c|c|c|c|c|c|c|c|c|c|c|}
\hline Animal & $\begin{array}{c}\text { Age } \\
\text { (Years) }\end{array}$ & BUN1 & BUN2 & Cr1 & $\mathrm{Cr} 2$ & U.D & PU:CU & $\mathrm{Na}$ & $\mathrm{K}$ & Cai & $\mathbf{P}$ & $\mathrm{T} 4 \mathrm{t}$ & BP1 & BP2 & USG & $\begin{array}{l}\text { Stagin of } \\
\text { CKD }\end{array}$ \\
\hline \multicolumn{17}{|c|}{ Hypertrophic cardiomyopathy } \\
\hline 1 & 5 & 53 & 48 & 1.3 & 1.3 & 1030 & 0.3 & 140 & 4.1 & 1.4 & 3.8 & 24.3 & 139 & -- & $\mathrm{N}$ & At Risk \\
\hline 2 & 2 & 28 & 30 & 1.3 & 1.3 & 1050 & 1.69 & 148 & 4.3 & 1.3 & 3.6 & 22.6 & 140 & -- & $\mathrm{N}$ & At Risk \\
\hline 3 & 5 & 105 & 102 & 1.9 & 1.9 & 1028 & 0.28 & 139 & 3.8 & 1.13 & 5.6 & 28.8 & 139 & -- & Ch & II \\
\hline 4 & 8 & 97 & 80 & 2.0 & 2.0 & 1026 & 0.1 & 137 & 4.8 & 1.23 & 8.2 & 26.7 & 140 & -- & Ch & II \\
\hline 5 & 9 & 45 & 56 & 1.5 & 1.6 & 1050 & 0.17 & 143 & 4.4 & 1.25 & 7.9 & 22.6 & 161 & 138 & $\mathrm{Ch}$ & I \\
\hline \multicolumn{17}{|c|}{ Concentric Hypertrophy of the Left Ventricle } \\
\hline 6 & 19 & 89 & 106 & 2.6 & 2.1 & 1012 & 0.3 & 137 & 4 & 1.1 & 17 & 28.8 & 223 & 220 & Ch & II \\
\hline 7 & 7 & 52 & 48 & 1.5 & 1.3 & 1030 & 0.2 & 140 & 4.9 & 1.26 & 6.6 & 36.4 & 123 & -- & $\mathrm{N}$ & At Risk \\
\hline 8 & 17 & 89 & * & 2.3 & * & * & $*$ & 150 & 3.9 & 0.87 & 7 & 34.5 & 161 & $*$ & $\mathrm{Ch}$ & II \\
\hline 9 & 13 & 90 & 75 & 0.9 & 1 & 1046 & 0.53 & 146 & 3.2 & 1.1 & 4 & 89.3 & 138 & -- & Ch & I \\
\hline 10 & 18 & 88 & 98 & 1.4 & 1.5 & 1025 & 0.7 & 144 & 2.6 & 1.2 & 3.6 & 78 & 122 & -- & Ch & I \\
\hline
\end{tabular}

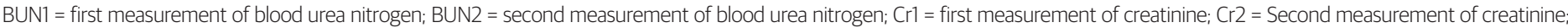

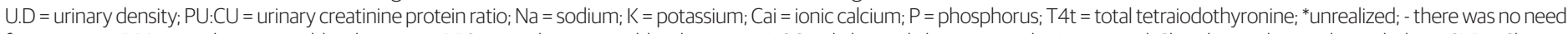

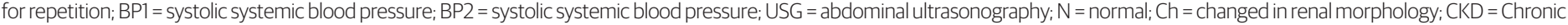
Kidney Disease. 
Table 2. Doppler echocardiography (in cm) in the M-mode of random bred cats, with hypertrophic cardiomyopathy and secondary concentric ventricular hypertrophy.

\begin{tabular}{|c|c|c|c|c|c|c|c|c|c|c|c|c|}
\hline Animal & LA & LA/AO & VSd & VSs & LVWd & LVWs & LVd & LVs & AoVmax & AoGrP & SF & EF \\
\hline \multicolumn{13}{|c|}{ Hypertrophic cardiomyopathy } \\
\hline 1 & 1.25 & 0.98 & 0.52 & 0.6 & 0.52 & 0.8 & 1.25 & 0.71 & 0.88 & 3.1 & 43 & 78 \\
\hline 2 & 1.27 & 1.4 & 0.57 & 0.91 & 0.39 & 0.44 & 1.37 & 0.75 & 0.86 & 2.9 & 45 & 80 \\
\hline 3 & 1.8 & 1.63 & 0.55 & 0.97 & 0.52 & 0.93 & 1.93 & 0.97 & 0.98 & 3.9 & 50 & 84 \\
\hline 4 & 1.49 & 1.16 & 0.46 & 1.04 & 0.55 & 1.07 & 1.66 & 0.41 & 1.09 & 4.7 & 75 & 98 \\
\hline 5 & 1.62 & 1.42 & 0.66 & 0.83 & 0.41 & 0.69 & 1.38 & 0.66 & 0.88 & 3.1 & 53 & 87 \\
\hline Mean & $1.49^{a} \pm 0.23$ & $1.32 \pm 0.25$ & $0.55 \pm 0.07$ & $0.87 \pm 0.17$ & $0.48^{a} \pm 0.07$ & $0.79 \pm 0.24$ & $1.52^{\mathrm{a}} \pm 0.28$ & $0.7^{a} \pm 0.20$ & $0.94 \pm 0.10$ & $3.54 \pm 0.75$ & $53.2 \pm 12.81$ & $85.4 \pm 7.86$ \\
\hline C.V & 0.16 & 0.19 & 0.13 & 0.19 & 0.15 & 0.31 & 0.18 & 0.29 & 0.10 & 0.21 & 0.24 & 0.09 \\
\hline \multicolumn{13}{|c|}{ Concentric Hypertrophy of the Left Ventricle } \\
\hline 6 & 1.06 & 1.16 & 0.56 & 0.8 & 0.5 & 0.8 & 1.14 & 0.62 & 0.97 & 3.8 & 55 & 89 \\
\hline 7 & 1.16 & 1.15 & 0.52 & 1.01 & 0.67 & 0.79 & 1.34 & 0.61 & 0.92 & 3.4 & 55 & 88 \\
\hline 8 & 1.16 & 1.29 & 0.56 & 0.78 & 0.54 & 0.78 & 1.25 & 0.6 & 0.88 & 3.1 & 52 & 86 \\
\hline 9 & 1.28 & 1.35 & 0.59 & 0.86 & 0.59 & 0.97 & 1.24 & 0.41 & 1.2 & 5.7 & 67 & 95 \\
\hline 10 & 1.27 & 1.23 & 0.52 & 0.8 & 0.62 & 0.75 & 1.24 & 0.6 & 0.88 & 3.1 & 52 & 87 \\
\hline Mean & $1.19^{b} \pm 0.1$ & $1.24 \pm 0.1$ & $0.55 \pm 0.03$ & $0.85 \pm 0.1$ & $0.58^{b} \pm 0.1$ & $0.82 \pm 0.1$ & $1.24^{\mathrm{b}} \pm 0.1$ & $0.57^{b} \pm 0.1$ & $0.97 \pm 0.5$ & $3.82 \pm 0.3$ & $56.2 \pm 6.2$ & $89.0 \pm 3.5$ \\
\hline C.V & 0.1 & 0.1 & 0.1 & 0.1 & 0.1 & 0.1 & 0.1 & 0.2 & 0.9 & 0.1 & 0.1 & 0.04 \\
\hline
\end{tabular}

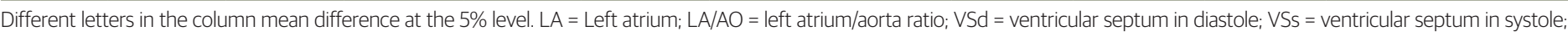

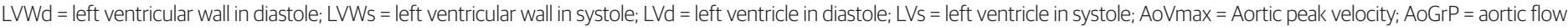
pressure gradient; $\mathrm{SF}=$ shortening fraction; $\mathrm{EF}=$ ejection fraction; $\mathrm{C} . \mathrm{V}=$ coefficient of variation.

Hyperthyroidism was the main cause of CLVH among the included cats and their age range matches the expected range for the occurrence of hyperthyroidism (Peterson, 2012; Vaske et al., 2016), reinforcing that monitoring hyperthyroidism cats heart is a requirement for good veterinary procedures. Furthermore, young adult cats were the most HCM affected (5.8 \pm 2.8 years) what, although does not contradicts previous reports $(8,19)$, when analysed along with the age range detected for CLVH cats (14.8 \pm 4.9 years) suggests that hyperthyroidism CLVH cats could have been hypertrophic before developing the thyroid dysfunction. Therefore, longitudinal cohort studies are needed to establish cause and effect.

Once the previous clinical history of the chronic kidney disease cat was unavailable, the same rational can be extrapolated; the cat could have presented primary hypertension previously, what could have induced either left ventricle wall hypertrophy or the kidney disease (Acierno et al., 2018). Among the cats that were characterized as hypertensive, one presented CKD (sustained azotemia, low urinary density and altered renal morphology). It can be inferred that CKD has caused the blood hypertension and consequently secondary ventricular hypertrophy (International Renal Interest Society, 2017; Brown et al., 2007), but it is impossible to rule out primary hypertension as cause of the renal injury and ventricular hypertrophy in consequence (Acierno et al., 2018; Pouchelon et al., 2015). There were no previous exams as well as BP measurements prior to evaluation. No cat was diagnosed with primary hypertension although it has been reported in 13 to 20\% of the feline population (Maggio et al., 2000; Elliott et al., 2001; Jepson et al., 2007).

One animal died (N.8) and had BP measured only once. However, in addition to hypertension, it had increased levels of total T4, azotemia, low urinary density, altered renal morphology and blood hypertension, alterations that allow to consider that ventricular hypertrophy diagnosed at echocardiographic examination was related to secondary disease, although it was impossible to determine which one was responsible for cardiac chances (hyperthyroidism, chronic kidney disease and hypertension), or even though if they were associated in this condition (Acierno et al., 2018; Brown et al., 2007). 
In CKD stage II cats (2 HCM cats and 1 CLVH due to hyperthyroidism) (showing discrete renal azotemia and absence of clinical signs) (International Renal Interest Society, 2017) without hypertension, concentric ventricular hypertrophy was not considered to be a consequence of the renal disease. One CKD stage II animal (N.6) presented sustained azotemia, low urinary density and blood hypertension, therefore. CKD was considered to be the cause of the CLVH. It is important to consider that CKD as the cause of ventricular hypertrophy is not fully elucidated among domestic animals, therefore hypertension along with laboratory findings (Table 1) was considered to be determinant of the chronic pressure overload (Brown et al., 2007; Pouchelon et al., 2015; Maggio et al., 2000; Maciel, 2001; Ronco \& Di Lullo, 2014).

Hyperphosphatemia was present in all stage II CKD animals (Table 1), therefore it is important to mention that it could have stimulated the production of parathormone (Kogica et al., 2015), which could lead to cardiovascular disorders such as hypertrophy, as described in humans (Neves et al., 2008). Since there is no scientific evidence associating hyperparathyroidism with concentric ventricular hypertrophy in small animals medicine it was impossible to include hyperphosphatemia as an etiologic factor ventricular hypertrophy.

The biatrial increase in the evaluation of the cardiac silhouette is a radiographic alteration that in the past was highly related to the presence of feline hypertrophic cardiomyopathy, however, Winter et al. (2015), in his study, found a low correlation between this radiographic finding and the disease in question, considering that the biatrial increase may be present in different feline cardiomyopathies.

Since the right atrial enlargement observed in chest x-rays of 6 cats (60\%) was not concomitant with left atrial remodeling, it was considered to be an independent finding (Oura et al., 2015).

When the mean values of left ventricular cavity diameter measurements in systole and diastole were compared, the animals with CLVH had a smaller diameter at both moments, suggesting that the hypertrophy in these animals causes reduction of ventricular relaxation, reflected in a lower final diastolic volume, besides greater ejection fraction, resulting in a lower final systolic volume. These findings suggest that diseases that occur in $\mathrm{CLVH}$, generate more pronounced hypertrophy. This evidence is reinforced when analyzing the means of both the shortening fraction and the ejection fraction of the CLVH animals, which are larger than those of the HCM cats. Although there was no statistical difference, these findings, together with the results of aortic flow velocity and pressure gradient, which also had their mean measurements greater in CLVH cats, suggest that in these animals a higher ventricular and hemodynamic response on account of hypertrophy is occurring.

On the echocardiographic examination the size of the left atrium of HCM cats was greater than the size of the left atrium CLVH animals, which may suggest that cats with HCM present a tendency to volume overload of the left atrium greater than the CLVH cats. However, the CLVH animals, although presenting a hypertrophic process more pronounced than the animals with HCM, presented no atrial overload. As the ventricular hypertrophies were differently distributed between the two groups of cats, it may be suggested that the magnitude of the atrial overload has more to do with the form the hypertrophy is presented than to its intensity in itself, at least in the initial stages of disease (Côté et al., 2011b; Sampedrano et al., 2006; Ferasin, 2009a).

LA enlargement was increased in one HCM animal (N.3). This same animal presented hypertrophy of the interventricular septum and of the left ventricular wall in both systole and diastole. It is believed that LA enlargement may be an initial reflection of the difficulty of this chamber in pumping blood into the left ventricle, due to a greater resistance generated by hypertrophy. The finding of both septum and left ventricular wall hypertrophy in diastole without reducing the final diastolic and systolic volume may lead to the diagnosis of unclassified feline cardiomyopathy, although it may also be a stage of evolution of HCM (Sampedrano et al., 2006; Ferasin, 2009a, 2009b).

\section{Conclusion}

Considering the diagnosis of concentric ventricular hypertrophy, other diseases should be investigated and ruled out, such as hyperthyroidism, which was the main cause of secondary concentric hypertrophy in the present study. Although sensitive in the detection of concentric hypertrophy, echocardiographic findings are similar regardless of the cause of hypertrophy, as 
well as clinical and epidemiological aspects it is also necessary to monitor cardiac changes of CLVH closely, since their phenotypic manifestation was more severe than those observed in the animals with HCM. However, to determine whether disease progression in CLVH animals is faster than in HCM, further epidemiological studies are necessary.

\section{Acknowledgements}

To Professor Norma Labarthe (FIOCRUZ-RJ, Brazil) for the collaboration in the study.

\section{References}

Abbott, J. A. (2010). Feline hypertrophic cardiomyopathy: an update. The Veterinary Clinics of North America. Small Animal Practice, 40(4), 685-700. http://dx.doi.org/10.1016/j.cvsm.2010.04.004. PMid:20610019.

Acierno, M. J., Brown, S., Coleman, A. E., Jepson, R. E., Papich, M., Stepien, R. L., \& Syme, H. M. (2018). ACVIM consensus statement: guidelines for the identification, evaluation, and management of systemic hypertension in dogs and cats. Journal of Veterinary Internal Medicine, 32(6), 1803-1822. http://dx.doi.org/10.1111/jvim.15331. PMid:30353952.

Branquinho, J., Monzo, M., Cláudio, J. L. M. D., Rosado, M., Carvalho, J. L., Lacerda, R., \& Rodrigues, K. (2010). Diagnóstico imaginológico de cardiomiopatia hipertrófica. Revista Lusófona de Ciência e Medicina Veterinária, 3, 36-44.

Brown, S., Atkins, C., Bagley, R., Carr, A., Cowgill, L., Davidson, M., Egner, B., Elliott, J., Henik, R., Labato, M., Littman, M., Polzin, D., Ross, L., Snyder, P., \& Stepien, R. (2007). Guidelines for the identification, evaluation, and management of systemic hypertension in dogs and cats. Journal of Veterinary Internal Medicine, 21(3), 542-558. http://dx.doi.org/10.1111/j.1939-1676.2007.tb03005.x. PMid:17552466.

Chetboul, V., Petit, A., Gouni, V., Trehiou-Sechi, E., Misbach, C., Balouka, D., Carlos Sampedrano, C., Pouchelon, J. L., Tissier, R., \& Abitbol, M. (2012). Prospective echocardiographic and tissue Doppler screening of a large Sphynx cat population: reference ranges, heart disease prevalence and genetic aspects. Journal of Veterinary Cardiology, 14(4), 497-509. http://dx.doi.org/10.1016/j.jvc.2012.08.001. PMid:23131204.

Côté, E., MacDonald, K. A., Meurs, K. M., \& Sleeper, M. M. (2011a). Endocrine diseases. In E. Côté, K. A. MacDonald, K. M. Meurs \& M. M. Sleeper (Eds.), Feline cardiology (1st ed., pp. 395-407). West Sussex: Wiley-Blackwell. http://dx.doi.org/10.1002/9781118785782.

Côté, E., MacDonald, K. A., Meurs, K. M., \& Sleeper, M. M. (2011b). Hypertrophic cardiomyopathy. In E. Côté, K. A. MacDonald, K. M. Meurs \& M. M. Sleeper (Eds.), Feline cardiology (1st ed., pp. 103-175). West Sussex: WileyBlackel. http://dx.doi.org/10.1002/9781118785782.

Elliott, J., Barber, P. J., Syme, H. M., Rawlings, J. M., \& Markwell, P. J. (2001). Feline hypertension: clinical findings and response to antihypertensive treatment in 30 cases. The Journal of Small Animal Practice, 42(3), 122-129. http://dx.doi.org/10.1111/j.1748-5827.2001.tb02008.x. PMid:11303854.

Ferasin, L. (2009a). Feline myocardial disease 1: classifications, pathophysiology and clinical presentation. Journal of Feline Medicine and Surgery, 11(1), 3-13. http://dx.doi.org/10.1016/j.jfms.2008.11.008. PMid:19154970.

Ferasin, L. (2009b). Feline myocardial disease 2: diagnosis, prognosis and clinical management. Journal of Feline Medicine and Surgery, 11(3), 183-194. http://dx.doi.org/10.1016/j.jfms.2009.01.002. PMid:19237134.

Fox, P. R. (1999). Feline myocardial diseases. In P. R. Fox, D. D. Sisson \& S. N. Moise (Eds.), Textbook of canine and feline cardiology principles and practice (2nd ed., pp. 621-678). Philadelphia: WB Saunders.

Häggström, J., Andersson, O., Falk, T., Nilsfors, L., OIsson, U., Kresken, J. G., Höglund, K., Rishniw, M., Tidholm, A., \& Ljungvall, I. (2016). Effect of body weight on echocardiographic measurements in 19,866 pure-bred cats with or without heart disease. Journal of Veterinary Internal Medicine, 30(5), 1601-1611. http://dx.doi. org/10.1111/jvim.14569. PMid:27573384.

International Renal Interest Society. (2017). Staging of CKD. IRIS. Retrieved in 2019, January 20, from http:// www.iriskidney.com/guidelines/en/staging/ckd.shtml

Jepson, R. E., Elliott, J., Brodbelt, D., \& Syme, H. M. (2007). Effect of control of systolic blood pressure on survival in cats with systemic hypertension. Journal of Veterinary Internal Medicine, 21(3), 402-409. http://dx.doi. org/10.1111/j.1939-1676.2007.tb02982.x. PMid:17552443.

Kogica, M., Waki, M., \& Martorelli, C. (2015). Doença renal crônica. In M. Jericó, J. Andrade Neto \& M. Kogika (Eds.), Tratado de medicina interna de cães e gatos (1a ed., pp. 1394-1409). Rio de Janeiro: Roca.

Maciel, B. C. (2001). A hipertrofia cardíaca na hipertensão arterial sistêmica: mecanismo compensatório e desencadeante de insuficiência cardíaca. Revista Brasileira de Hipertensão, 8, 409-413.

Maggio, F., DeFrancesco, T. C., Atkins, C. E., Pizzirani, S., Gilger, B. C., \& Davidson, M. G. (2000). Ocular lesions associated with systemic hypertension in cats: 69 cases (1985-1998). Journal of the American Veterinary Medical Association, 217(5), 695-702. http://dx.doi.org/10.2460/javma.2000.217.695. PMid:10976302. 
Marino, C. L., Lascelles, B. D., Vaden, S. L., Gruen, M. E., \& Marks, S. L. (2014). Prevalence and classification of chronic kidney disease in cats randomly selected from four age groups and in cats recruited for degenerative joint disease studies. Journal of Feline Medicine and Surgery, 16(6), 465-472. http://dx.doi.org/10.1177/1098612X13511446. PMid:24217707.

Maron, B., Roberts, W., \& Epstein, S. (1982). Sudden death in hypertrophic cardiomyopathy: a profile of 78 patients. Circulation, 65(7), 1388-1394. http://dx.doi.org/10.1161/01.CIR.65.7.1388. PMid:7200406.

Meurs, K. M., Norgard, M. M., Ederer, M. M., Hendrix, K. P., \& Kittleson, M. D. (2007). A substitution mutation in the myosin binding protein C gene in ragdoll hypertrophic cardiomyopathy. Genomics, 90(2), 261-264. http:// dx.doi.org/10.1016/j.ygeno.2007.04.007. PMid:17521870.

Meurs, K. M., Sanchez, X., David, R. M., Bowles, N. E., Towbin, J. A., Reiser, P. J., Kittleson, J. A., Munro, M. J., Dryburgh, K., Macdonald, K. A., \& Kittleson, M. D. (2005). A cardiac myosin binding protein C mutation in the Maine Coon cat with familial hypertrophic cardiomyopathy. Human Molecular Genetics, 14(23), 3587-3593. http://dx.doi.org/10.1093/hmg/ddi386. PMid:16236761.

Neves, C. L., Custódio, M. R., Neves, K. R., Moysés, R. M. A., \& Jorgetti, V. (2008). O hiperparatireoidismo secundário e a doença cardiovascular na doença renal crônica. Jornal Brasileiro de Nefrologia, 30, 18-22.

Oura, T. J., Young, A. N., Keene, B. W., Robertson, I. D., Jennings, D. E., \& Thrall, D. E. (2015). Valentine-shaped cardiac silhouette in feline thoracic radiographs is primarily due to left atrial enlargement. Veterinary Radiology \& Ultrasound, 56(3), 245-250. http://dx.doi.org/10.1111/vru.12221. PMid:25404557.

Paige, C. F., Abbott, J. A., Elvinger, F., \& Pyle, R. L. (2009). Prevalence of cardiomyopathy in apparently healthy cats. Journal of the American Veterinary Medical Association, 234(11), 1398-1403. http://dx.doi.org/10.2460/ javma.234.11.1398. PMid:19480619.

Peterson, M. E. (2012). Hyperthyroidism in cats: what's causing this epidemic of thyroid disease and can we prevent it? Journal of Feline Medicine and Surgery, 14(11), 804-818. http://dx.doi.org/10.1177/1098612X12464462. PMid:23087006.

Pouchelon, J. L., Atkins, C. E., Bussadori, C., Oyama, M. A., Vaden, S. L., Bonagura, J. D., Chetboul, V., Cowgill, L. D., Elliot, J., Francey, T., Grauer, G. F., Luis Fuentes, V., Sydney Moise, N., Polzin, D. J., Van Dongen, A. M., \& Van Israël, N. (2015). Cardiovascular-renal axis disorders in the domestic dog and cat: a veterinary consensus statement. The Journal of Small Animal Practice, 56(9), 537-552. http://dx.doi.org/10.1111/jsap.12387. PMid:26331869.

Ronco, C., \& Di Lullo, L. (2014). Cardiorenal syndrome. Heart Failure Clinics, 10(2), 251-280. http://dx.doi.org/10.1016/j. hfc.2013.12.003. PMid:24656104.

Rush, J. E., Freeman, L. M., Fenollosa, N. K., \& Brown, D. J. (2002). Population and survival characteristics of cats with hypertrophic cardiomyopathy: 260 cases (1990-1999). Journal of the American Veterinary Medical Association, 220(2), 202-207. http://dx.doi.org/10.2460/javma.2002.220.202. PMid:12126131.

Sampedrano, C. C., Chetboul, V., Gouni, V., Nicolle, A. P., Pouchelon, J.-L., \& Tissier, R. (2006). Systolic and diastolic myocardial dysfunction in cats with hypertrophic cardiomyopathy or systemic hypertension. Journal of Veterinary Internal Medicine, 20(5), 1106-1115. http://dx.doi.org/10.1111/j.1939-1676.2006.tb00708.x. PMid:17063702.

Trehiou-Sechi, E., Tissier, R., Gouni, V., Misbach, C., Petit, A. M. P., Balouka, D., Carlos Sampedrano, C., Castaignet, M., Pouchelon, J.-L., \& Chetboul, V. (2012). Comparative echocardiographic and clinical features of hypertrophic cardiomyopathy in 5 breeds of cats: a retrospective analysis of 344 cases (2001-2011). Journal of Veterinary Internal Medicine, 26(3), 532-541. http://dx.doi.org/10.1111/j.1939-1676.2012.00906.x. PMid:22443341.

Vaske, H. H., Schermerhorn, T., \& Grauer, G. F. (2016). Effects of feline hyperthyroidism on kidney function: a review. Journal of Feline Medicine and Surgery, 18(2), 55-59. http://dx.doi.org/10.1177/1098612X15575385. PMid:25749888.

Ware, W. E. (2011). Myocardial disease of the cat. In W. Ware(Ed.), Cardiovascular disease in small animal medicine (1st ed., pp. 300-310). London: Manson Publishing. http://dx.doi.org/10.1201/b15177-25.

Winter, M. D., Giglio, R. F., Berry, C. R., Reese, D. J., Maisenbacher, H. W., \& Hernandez, J. A. (2015). Associations between 'valentine' heart shape, atrial enlargement and cardiomyopathy in cats. Journal of Feline Medicine and Surgery, 17(6), 447. PMid:25146363. 